\title{
Klatskin tumor presented with melena and jaundice: interesting case with hemobilia
}

\author{
Melaena ve sarılık ile seyreden Klatskin tümörü; ilginç bir hemobili olgusu \\ Diğdem ÖZER ETIK, Öykü Tayfur YÜREKLİ, Bülent ÖDEMIŞ, Selçuk DIŞIBEYYAZ, Erkan PARLAK \\ Department of Gastroenterology, Türkiye Yüksek Ihtisas Hospital, Ankara
}

Hemobilia bleeding into the biliary tree is an unusual cause of upper gastrointestinal bleeding. Generally, etiologies of hemobilia are iatrogenic or traumatic in origin. Cholangiocarcinoma is a rare gastrointestinal tumor that can become evident with hemobilia. We present a 77-year-old female with a history of warfarin use, who suffered from a protracted course of melena and jaundice.

Key words: Hemobilia, warfarin, cholangiocarcinoma

\section{INTRODUCTION}

Hemobilia is quite a rare cause of upper gastrointestinal system bleeding. This definition relating to the presence of bleeding within the biliary system was used for the first time by Sandblom in 1948 (1). The majority of the hemobilia cases report iatrogenic trauma history including random trauma or liver biopsies relating to the hepatobiliary system. Biliary stone diseases such as cholecystitis and cholangitis, parasitic infections of the biliary duct, liver abscess, hepatobiliary malignancies, vascular malformations or aneurysm of the hepatic artery, and coagulopathy are among other causes of hemobilia $(1,2)$.

Cholangiocellular carcinoma, on the other hand, constitutes 2-3\% of all gastrointestinal system tumors, mostly presenting with painless jaundice and itching. Hemobilia may also occur following endoscopic interventions including drainage into the biliary system or secondary to hepatic arterial fistulas or aneurysms that develop after local therapies in cholangiocellular carcinoma $(3,4)$. We herein present a case using warfarin who was diagnosed with non-traumatic hemobilia and malignant hilar stenosis at the time of her presentation with melena.

\section{CASE REPORT}

A 77-year-old female applied to emergency service with the complaint of melena lasting for one week. Her history indicated use of angiotensin receptor blocker, beta blocker and warfarin due to hypertension and atrial fibrillation. Her systemic examination revealed Blood pressure: 100/60 mmHg Pulsati-
Hemobili, safra yollarına kanama olmasıdır. Üst gastrointestinal kanamalarının nadir bir nedenidir. Hemobilinin en sik etiyolojik nedeni iyatrojenik veya travmatik olaylardır. Kolanjiokarsinom, nadir bir gastrointesinal tümör olup hemobili ile ortaya çıkabilir. Burada 77 yaşında, varfarin kullanan, uzamıș melaena ve sarılık șikayeti ile gelen bir olguyu sunmaktayız.

Anahtar kelimeler: Hemobili, varfarin, kolanjiokarsinom

on: 110 pulse/min arrhythmia. The patient manifested a good general condition with open conscious, and good cooperation and orientation. Her skin was icteric. Abdominal examination did not indicate any pathological finding, with rectal touch concordant with melena. Her laboratory tests at the time of referral indicated: hemoglobin (Hb): $9.9 \mathrm{~g} / \mathrm{dl}$, hematocrit (Hct): $32.5 \%$, platelets (Plt): $186,000 / \mathrm{mm}^{3}$, WBC: $4300 / \mathrm{mm}^{3}$, unrecognizable levels of international normalized ratio (INR) and

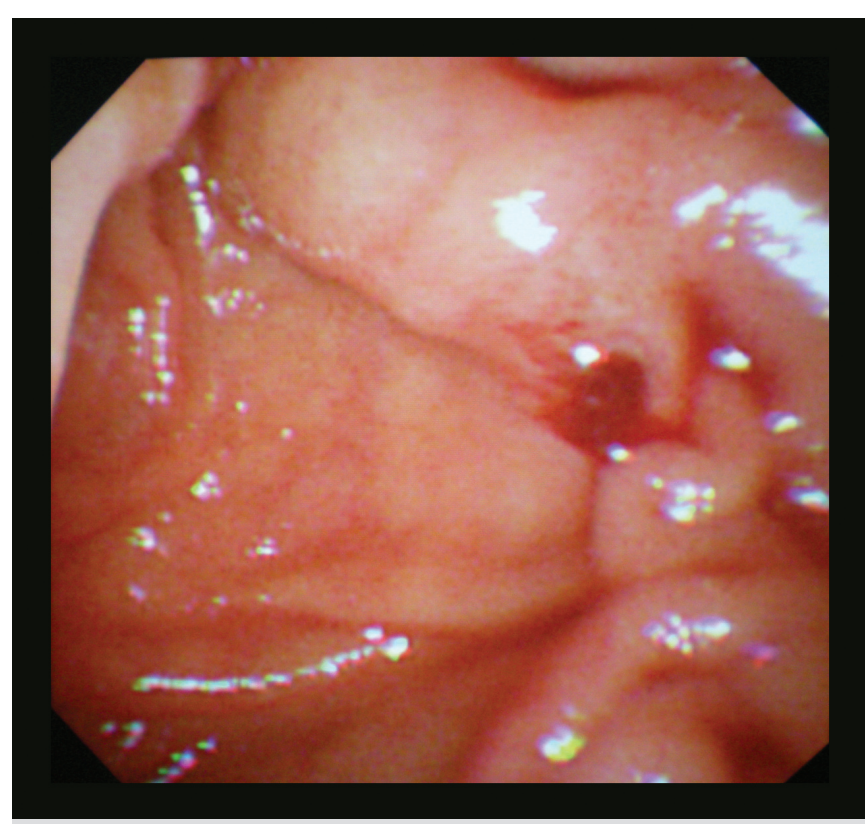

Figure 1. Duodenoscopic view of bleeding from the major papilla.
Correspondence: Diğdem Özer ETIK 8. Cadde 75. Sokak No: 22/6 Emek / Ankara / Turkey Faks: + 903123061000 • E-mail: digdemozer@hotmail.com Manuscript received: 25.02.2011 Accepted: 19.03.2011 


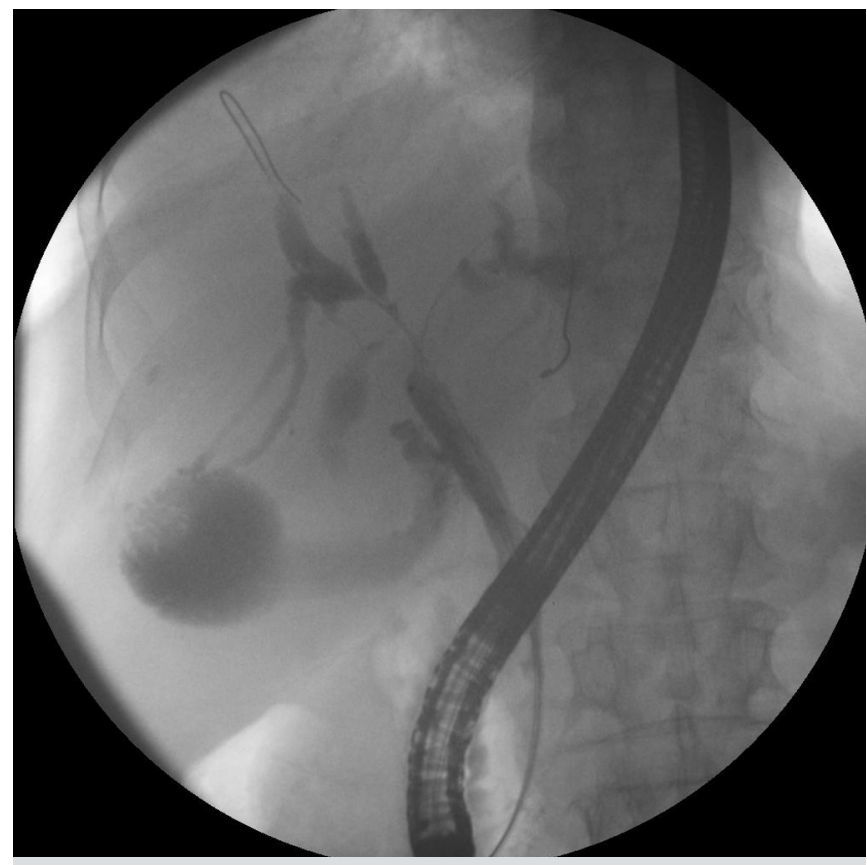

Figure 2. Malignant hilar stenosis.

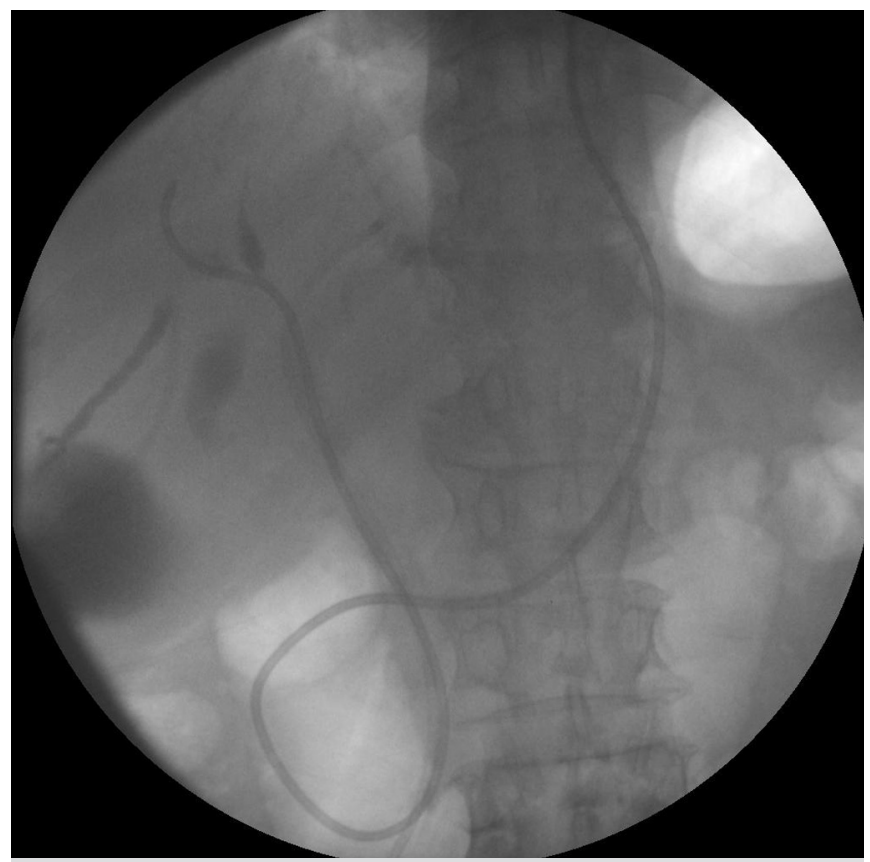

Figure 3. Nasobiliary drain and stent placed by crossing over the stenosis. prothrombin time (PTT), urea: $87 \mathrm{mg} / \mathrm{dl}$, creatinine: 0.9 $\mathrm{mg} / \mathrm{dl}$, and aspartate aminotransferase (AST): 79 IU/L. At first, endoscopy following fresh frozen plasma and erythrocyte replacement was planned for suspected upper gastrointestinal system bleeding triggered by warfarin. Blood workup and hepatobiliary ultrasonography (USG) were also planned due to the patient's icteric appearance and defined itching in her anamnesis. Endoscopic intervention was performed when her INR was detected as 2.9 following blood product replacement. There was no gastric pathology in esophago-gastrography to indicate bleeding, but bleeding was observed from the outlet of the major papilla. Biochemical laboratory tests revealed alanine aminotransferase (ALT): 50 IU/L, alkaline phosphatase (ALP): $250 \mathrm{IU} / \mathrm{L}$, gamma-glutamyl transpeptidase (GGT): 136 IU/L, total bilirubin: $21 \mathrm{mg} / \mathrm{dl}$, direct bilirubin: $17 \mathrm{mg} / \mathrm{dl}$, hepatitis markers: negative, and CA 19-9: 1340 U/ml. Hepatobiliary USG indicated contracted sac, bilaterally dilated intrahepatic bile duct, and abrupt discontinuation of the tissue density on the bile duct at the level of the choledochus. Size, parenchyma, contours, and vascular structures of the liver were normal. Thus, endoscopic retrograde cholangiopancreatography (ERCP) was performed both for diagnostic and therapeutic purposes. ERCP indicated a leak-type bleeding from the major papilla (Figure 1). Since INR elevation continued, the choledochus was cannulized without sphincterectomy. An irregular stenosis was detected at the hilar level dividing the right segmental branches (Figure 2). The suspected diagnosis was Bismuth type IIIa cholangiocellular carcinoma considering the patient's advanced age, absence of biliary history, melena secondary to hemobilia, painless jaundice and itching symptoms, severe elevation of CA 19-9 level, and ERCP findings. Luminal aspirations during ERCP indicated ongoing bleeding from the duct. A 7F nasobiliary drain and 10F $16 \mathrm{~cm}$ biliary stent were placed crossing over the stenosis (Figure 3). Her after-procedure follow-up indicated that the bleeding was under control and that she no longer needed erythrocyte replacement.

\section{DISCUSSION}

In geriatric patients, there is an elevated risk of gastrointestinal bleeding due to intensive use of anti-aggregates and anticoagulants against cardiac comorbidities. However, peptic ulcer conditions rank first in the etiology of all upper gastrointestinal system bleedings independent of age (5). However, in this case, who applied with melena and reported use of warfarin, the endoscopic examination revealed no esophago-gastroduodenal pathology. Her physical examination indicated icterus with elevated cholestasis parameters, which led us to consider a possible hemobilia. An insisted and thorough examination by the endoscopist revealed bleeding from the major papilla. The classic hemobilia triad comprises upper gastrointestinal bleeding, upper abdominal pain and jaundice (3). The most remarkable symptom of these three is hematemesis or melena, and the rarest jaundice. Prevalence of all three aspects of the classic triad is 22\%. Bismuth categorized causes of hemobilia in 1973 according to the etiology with relevance to the liver by $53 \%$, gall bladder by $23 \%$, biliary duct by $22 \%$, and pancreas by $2 \%(3,4)$. Abdominal USG indicates an obstruction in the bile duct, with an abrupt termination of the choledochus at the proximal end with tissue echo- 
genicity. Cholangiocellular carcinomas are gastrointestinal tumors with poor prognosis that are generally detected at an advanced stage. For this particular patient, use of anticoagulants facilitated bleeding in the tumor-infiltrated biliary system. The purpose of hemobilia treatment is to stop the bleeding and remove the biliary obstruction. For this purpose, angiographic transarterial embolization and biliary drainage with ERCP are recommended. The surgical method is only recom- mended when these methods are inapplicable or when they fail (6). Stenting with ERCP and nasobiliary drainage helped control the bleeding in this patient.

In conclusion, presence of jaundice accompanying melena should raise suspicion regarding the presence of hemobilia. Patients should also be examined for non-traumatic biliary diseases such as iatrogenic, traumatic, inflammatory, and parasitic conditions or malignancies.

\section{REFERENCES}

1. Thong-Ngam D, Shusang V, Wongkusoltham P, et al. Hemobilia: four case reports and review of the literature. J Med Assoc Thai 2001; 84: 438-44.

2. Manolakis AC, Kapsoritakis AN, Tsikouras AD, et al. Hemobilia as the initial manifestation of cholangiocarcinoma in a hemophilia B patient. World J Gastroenterol 2008; 14: 4241-4.

3. Killeen RP, Torreggiani WC, Malone DE, Brophy DP. Hemobilia as a potential complication in patients treated with photodynamic therapy for unresectable cholangiocarcinoma. Gastrointest Cancer Res 2009; 3: 80.

4. Hayano K, Miura F, Amano H, et al. Arterio-biliary fistula as rare complication of chemoradiation therapy for intrahepatic cholangiocarcinoma. World J Radiol 2010; 2: 374-6.

5. Lee TC, Huang SP, Yang JY, et al. Age is not a discriminating factor for outcomes of therapeutic upper gastrointestinal endoscopy. Hepatogastroenterology 2007; 54: 1319-22.

6. Rerknimitr R, Kongkam P, Kullavanijaya P. Treatment of tumor associated hemobilia with a partially covered metallic stent. Endoscopy 2007; 39: E225 